\title{
Comparison of different criteria used to categorize technological quality of pork
}

\section{Comparação de diferentes critérios utilizados para classificar a qualidade tecnológica da carne suína}

\author{
Henrique Pereira Cazedey ${ }^{\mathrm{I}}$ Robledo de Almeida Torres Filho ${ }^{\mathrm{II}}$ Paulo Rogério Fontes ${ }^{\mathrm{III}}$ \\ Alcinéia de Lemos Souza Ramos ${ }^{I}$ Eduardo Mendes Ramos ${ }^{I^{*}}$
}

\begin{abstract}
Pork may be classified into quality categories according to its color, texture and exudation, though no international consensus criterion has been reached yet. Thus, the aim of the present paper was to examine the relation between important meat quality traits, evaluating pork quality classification of a same data by different criteria proposed in the literature. In 60 pork loins (Longissimus thoracis muscle), initial $\mathrm{pH}\left(\mathrm{pH}_{45 \mathrm{~min}}\right)$ and $R$-value were evaluated after $45 \mathrm{~min}$ post mortem between the $9^{\text {th }}$ and $10^{\text {th }}$ ribs, and ultimate $\mathrm{pH}\left(\mathrm{pH}_{24 \mathrm{~h}}\right)$, objective color and water-holding capacity were evaluated $24 \mathrm{~h}$ post mortem in two $2.54 \mathrm{~cm}$ thick steaks cut between the $9^{\text {th }}$ and $11^{\text {th }}$ ribs to be classified into PSE (pale, soft and exudative), RSE (reddish-pink, soft and exudative), RFN (reddish-pink, firm and non-exudative) or DFD (dark, firm and dry) quality. Frequency distributions of quality categories differed $(P<0.001)$ among criteria, which resulted in large variations: 3 to 68\% PSE; 0 to $73 \%$ RSE; 5 to $68 \%$ RFN; 0 to $22 \%$ DFD; and 0 to $33 \%$ unclassified samples. A same sample may be classified into different quality categories according to the criterion utilized, which results in large variations in frequency distributions and also in quality attributes. Therefore, the classification of pork quality depends on the adopted criterion, which indicated the need for international standardization, so that pork quality can be determined efficiently and effectively.
\end{abstract}

Key words: PSE, DFD meat, color, exudation, $p H$.

\section{RESUMO}

A carne suína pode ser classificada em categorias de qualidade de acordo com sua cor, textura e exsudação, embora ainda não exista um critério internacional consensual. Desse modo, o objetivo do presente artigo foi verificar a relação entre importantes características de qualidade de carne, avaliando a classificação da qualidade da carne suína de um mesmo banco de dados por diferentes critérios propostos na literatura. Em 60 lombos (músculo Longissimus thoracis), $\mathrm{pH}$ inicial ( $\mathrm{pH}_{45 \mathrm{~min}}$ ) $e$ Valor $R$, foram avaliados 45 minutos post mortem entre a 9 a e a $10^{\underline{a}}$ costelas, e pH final ( $\left.\mathrm{pH}_{24}\right)$, cor objetiva e capacidade de retenção de água foram avaliados 24 horas post mortem, em dois bifes, com 2,54cm de espessura, cortados, entre a 9a e a 11a costelas, para serem classificados como PSE (pálida, flácida e exsudativa), RSE (vermelho-rosada, flácida e exsudativa), RFN (vermelhorosada, firme e não-exsudativa) ou DFD (escura, firme e seca). As distribuições de frequência das categorias de qualidade diferiram $(P<0,001)$ entre os critérios, resultando em grandes variações: 3 a 68\% PSE; 0 a 73\% RSE; 5 a 68\% RFN; 0 a 22\% DFD; $e 0$ a 33\% de amostras não classificadas. Uma mesma amostra pode ser classificada em diferentes categorias de qualidade, de acordo com o critério utilizado, o que resulta em grandes variações nas distribuições de frequência e também nos atributos de qualidade. Portanto, a classificação da qualidade da carne suína é dependente do critério adotado, evidenciando a necessidade de uma padronização internacional para a identificação eficiente e eficaz da qualidade da carne suína.

Palavras-chave: carne PSE e DFD, cor, exsudação, $p H$.

\section{INTRODUCTION}

Pork may be classified into different quality categories according to its color, texture and exudation. Top-quality meat has a reddish-pink color, firm texture and normal exudation (RFN), which is considered ideal for producers and consumers. Anomalous conditions may provide pale, soft and exudative (PSE), reddish-pink, soft and exudative

\footnotetext{
IDepartamento de Ciência dos Alimentos (DCA), Universidade Federal de Lavras (UFLA), PO Box 3037, 37200-000, Lavras, MG, Brasil. E-mail: emramos@dca.ufla.br. "Corresponding author.

IIInstituto de Ciências Exatas e Tecnológicas, Universidade Federal de Viçosa (UFV), Florestal, MG, Brasil.

IIIDepartamento de Tecnologia de Alimentos, Universidade Federal de Viçosa (UFV), Viçosa, MG, Brasil.
} 
(RSE) or dark, firm and dry (DFD) meat, which present bad appearance for consumers and are unsuitable for processing (WARNER et al., 1993; RAMOS \& GOMIDE, 2007; BARBUT et al., 2008). The PSE condition is one of the major problems faced by the meat industry, and because of its economic importance and high occurrence, this phenomenon has been studied for many years (WARRISS \& BROWN, 1987; WARNER et al., 1993; WARNER et al., 1997; HUFF-LONERGAN \& LONERGAN, 2005; TAO \& PENG, 2014). Brazilian research studies have reported the incidence of $10.1 \%$ (SANTIAGO et al., 2012), 22.8\% (MAGANHINI et al., 2007) and 46.4\% (CULAU et al., 2002) of PSE in meat industries in the south of the country.

Although the $\mathrm{pH}$ at $45 \mathrm{~min}$ post mortem $\left(\mathrm{pH}_{45 \min }\right)$ can be used as an indicator of the PSE condition, its application is limited, because it did not allow for the prediction of all quality categories (RAMOS \& GOMIDE, 2007). Besides, low correlations between $\mathrm{pH}_{45 \min }$ and subjectively determined quality have been discouraging (SOMERS et al., 1985; JOO et al., 2000). To classify the pork in different quality categories, several criteria have been proposed (HONIKEL \& FISHER, 1977; BENDALL \& SWATLAND, 1988; KAUFFMAN et al., 1993; WARNER et al., 1993; WARNER et al., 1997; MAGANHINI et al., 2007; FAUCITANO et al., 2010), but there is no international consensus on what criteria should be used.

The classification ability depends on the quality attributes utilized in the characterization of pork, which could explain the wide variation in the incidence of PSE reported in the literature. Many quality attributes have been utilized to classify pork, e.g.: only $\mathrm{pH}_{45 \min }$ (BENDALL and SWATLAND, 1988); $\mathrm{pH}_{45 \min }$ and R-value (HONIKEL \& FISHER, 1977); only lightness $\left(L^{*}\right)$ (MAGANHINI et al., $2007)$; $\mathrm{pH}$ at $24 \mathrm{~h}$ post mortem $\left(\mathrm{pH}_{24 \mathrm{~h}}\right), L^{*}$ and waterholding capacity (WHC), measured by percentage drip loss (PDL) (WARNER et al., 1997) or filter-paper wetness (FPW) (FAUCITANO et al., 2010); only $L^{*}$ and PDL (KAUFFMAN et al., 1993); and only $L^{*}$ and FPW (WARNER et al., 1993). Therefore, the aim of the present paper was to examine the relation between important meat quality traits, evaluating the pork quality classification of a same data by different criteria proposed in the literature.

\section{MATERIALS AND METHODS}

Samples from 60 pigs (commercial cross Large White x Landrace) weighing $105 \pm 10 \mathrm{~kg}$ were obtained (from 11 to 21 March 2014) in an abattoir located in Lavras, MG, Brazil. After $45 \mathrm{~min}$ post mortem, the initial $\mathrm{pH}\left(\mathrm{pH}_{45 \min }\right)$ and the $\mathrm{R}$-value were determined in the Longissimus thoracis muscle between the $9^{\text {th }}$ and $10^{\text {th }}$ ribs. Carcasses were identified and kept refrigerated $\left(1 \pm 1^{\circ} \mathrm{C}\right)$ for $24 \mathrm{~h}$, when two $2.5 \mathrm{~cm}$ thick steaks between the $9^{\text {th }}$ and $11^{\text {th }}$ ribs were removed, packed and transferred to the Laboratory of Meat and Meat Products (LabCarnes) at the Universidade Federal de Lavras for analysis of ultimate $\mathrm{pH}\left(\mathrm{pH}_{24 \mathrm{~h}}\right)$, instrumental color (CIELAB) and water-holding capacity (WHC).

The $\mathrm{pH}_{45 \min }$ and $\mathrm{pH}_{24 \mathrm{~h}}$ were measured $45 \mathrm{~min}$ and $24 \mathrm{~h}$ post mortem, respectively, by a portable $\mathrm{pH}$ meter HI99163 (Hanna Instruments) using a probe with stainless steel blade. The R-value was measured $45 \mathrm{~min}$ post mortem, in triplicate, according to the methodology described by HONIKEL \& FISHER (1977). Meat color was evaluated $24 \mathrm{~h}$ post mortem using a spectrophotometer CM-700 (Konica Minolta) with 8-mm aperture size, specular component excluded (SCE), illuminant $\mathrm{D}_{65}$ and $10^{\circ}$ angle of observer. After blooming for $30 \mathrm{~min}$, the CIE $L^{*} a^{*} b^{*}$ color coordinates were obtained from the average of five readings taken at different positions on the exposed meat surface (RAMOS \& GOMIDE, 2007).

Pork water-holding capacity (WHC) was evaluated $24 \mathrm{~h}$ post mortem by percentage drip loss (PDL) and filter-paper wetness (FPW) methods. The FPW test was performed according to the methodology described by KAUFFMAN et al. (1986), with some modifications. After $2.54 \mathrm{~cm}$ thick steak was exposed to the environment at room temperature $\left(\sim 20^{\circ} \mathrm{C}\right)$ for 30min (blooming), a preweighed qualitative filter paper $\left(125 \mathrm{~mm}\right.$ in diameter, Whatman ${ }^{\circledR}$ Grade 1$)$ was placed on the meat surface for $3 \mathrm{~s}$ and then weighed again. The FPW was expressed as the weight (mg) of the absorbed exudate. The PDL test was measured as the percentage of the weight loss of a standardized (about $40 \mathrm{~g}$ ) muscle sample during its suspension in a plastic pot for $48 \mathrm{~h}$ at $4{ }^{\circ} \mathrm{C}$ (HONIKEL et al., 1986).

Samples were classified into the following quality categories: PSE (pale, soft and exudative), RSE (red, soft and exudative), RFN (red, firm and nonexudative), or DFD (dark, firm and dry), according to $\mathrm{pH}_{24 \mathrm{~h}}, L^{*}$ and WHC (PDL or FPW) parameters proposed by different criteria obtained from the literature (Table 1). Samples were also classified based on: the $\mathrm{pH}_{45 \min }$, defined by BENDALL \& SWATLAND (1988) as PSE $\left(\mathrm{pH}_{45 \min }<5.80\right)$ and RFN $\left(\mathrm{pH}_{45 \min }>5.80\right)$; and $\mathrm{pH}_{45 \min }$ and $\mathrm{R}$-value, described by HONIKEL \& FISHER (1977) as PSE (R-value >1.05 and $\left.\mathrm{pH}_{45 \min }<5.90\right), \mathrm{RFN}(\mathrm{R}$-value $\leq 1.05)$ and DFD 
Table 1 - Classification of pork quality according to ultimate $\mathrm{pH}$, lightness $\left(L^{*}\right)$ and water holding capacity (WHC) parameters proposed by criteria obtained from the literature.

\begin{tabular}{|c|c|c|c|c|c|}
\hline \multirow{2}{*}{ Source } & \multirow{2}{*}{ Quality Categories } & \multirow{2}{*}{$\mathrm{pH}_{24 \mathrm{~h}}$} & \multirow{2}{*}{$L^{*}$} & \multicolumn{2}{|c|}{----WHC--- } \\
\hline & & & & PDL (\%) & FPW (mg) \\
\hline \multirow{4}{*}{ KAUFFMAN et al. (1993) } & PSE & - & $>58$ & $>5$ & - \\
\hline & RSE & - & $52-58$ & $>5$ & - \\
\hline & RFN & - & $52-58$ & $<5$ & - \\
\hline & DFD & - & $<52$ & $<5$ & - \\
\hline \multirow{4}{*}{ WARNER et al. (1997) } & PSE & $<6.0$ & $>50$ & $>5$ & - \\
\hline & RSE & $<6.0$ & $42-50$ & $>5$ & - \\
\hline & RFN & $<6.0$ & $42-50$ & $<5$ & - \\
\hline & DFD & $\geq 6.0$ & $<42$ & $<5$ & - \\
\hline \multirow{4}{*}{ WARNER et al. (1993) } & PSE & - & $>55$ & - & $>100$ \\
\hline & RSE & - & $47-55$ & - & $>100$ \\
\hline & RFN & - & $47-55$ & - & $<100$ \\
\hline & DFD & - & $<47$ & - & $<100$ \\
\hline \multirow{3}{*}{ MAGANHINI et al. (2007) } & PSE & - & $>53$ & - & - \\
\hline & RFN & - & $45-53$ & - & - \\
\hline & DFD & - & $<45$ & - & - \\
\hline \multirow{4}{*}{ FAUCITANO et al. (2010) } & PSE & $<6.0$ & $>50$ & - & $\geq 80$ \\
\hline & RSE & $<6.0$ & $43-48$ & - & $\geq 80$ \\
\hline & RFN & $<6.0$ & $43-48$ & - & $<80$ \\
\hline & DFD & $\geq 6.0$ & $<42$ & - & $<80$ \\
\hline
\end{tabular}

PSE = pale, soft and exudative; RSE = reddish-pink, soft and exudative; RFN = reddish-pink, firm and non-exudative; DFD = dark, firm and dry; $\mathrm{PDL}=$ percentage drip loss; and FPW = filter paper wetness.

(R-value $>1.05$ and $\mathrm{pH}_{45 \min }>5.95$ ). Samples that were not classified into any of these categories were identified as "unclassified" (UC).

The statistical analyses were performed on the software SAS 9.2 (SAS Institute Inc., Cary, NC, USA) at a significance level of $5 \%$. The chisquare test $\left(\chi^{2}\right)$ was applied to evaluate the frequency distributions of the pork quality categories among the evaluated criteria. For each criterion obtained in the literature, analysis of variance (ANOVA) and, when necessary, Tukey test were used to evaluate the differences of the quality attributes among the pork quality categories, excluding the unclassified samples. Pearson's correlation analysis was also performed among the quality attributes, whose coefficients $(r)$ were tested by Student's t-test.

\section{RESULTS AND DISCUSSION}

The frequency distributions of the pork quality categories differed $\left(\chi^{2}=511.11 ; \quad \mathrm{P}<0.001\right)$ among the evaluated criteria. Samples were classified into different categories according to the adopted criterion, which resulted in large variations in frequency distributions (Figure 1). Depending on the criterion adopted, 3 to $68 \%$ of the samples can be classified as PSE, whereas 5 to $68 \%$ of the samples can be classified as RFN. Among the criteria that contained RSE and DFD categories, up to $73 \%$ of the samples can be classified as RSE, whereas up to $22 \%$ of the samples can be classified as DFD.

WARNER et al. (1997) and FAUCITANO et al. (2010) suggested a classification based on $\mathrm{pH}_{24 \mathrm{~h}}$, $L^{*}$ and WHC (PDL or FPW), though it is hard for a sample to meet, at the same time, the three parameters of a same category. So, these two criteria were the most strict regarding the pork quality, classifying 60 to $68 \%$ of the samples as PSE and 73 to $88 \%$ of them as soft and exudative (PSE + RSE).

The $\mathrm{pH}$ and $L^{*}$ values is known to be strong related to $\mathrm{WHC}$, but the magnitude of correlation differs between studies (OTTO et al., 2004). In the 


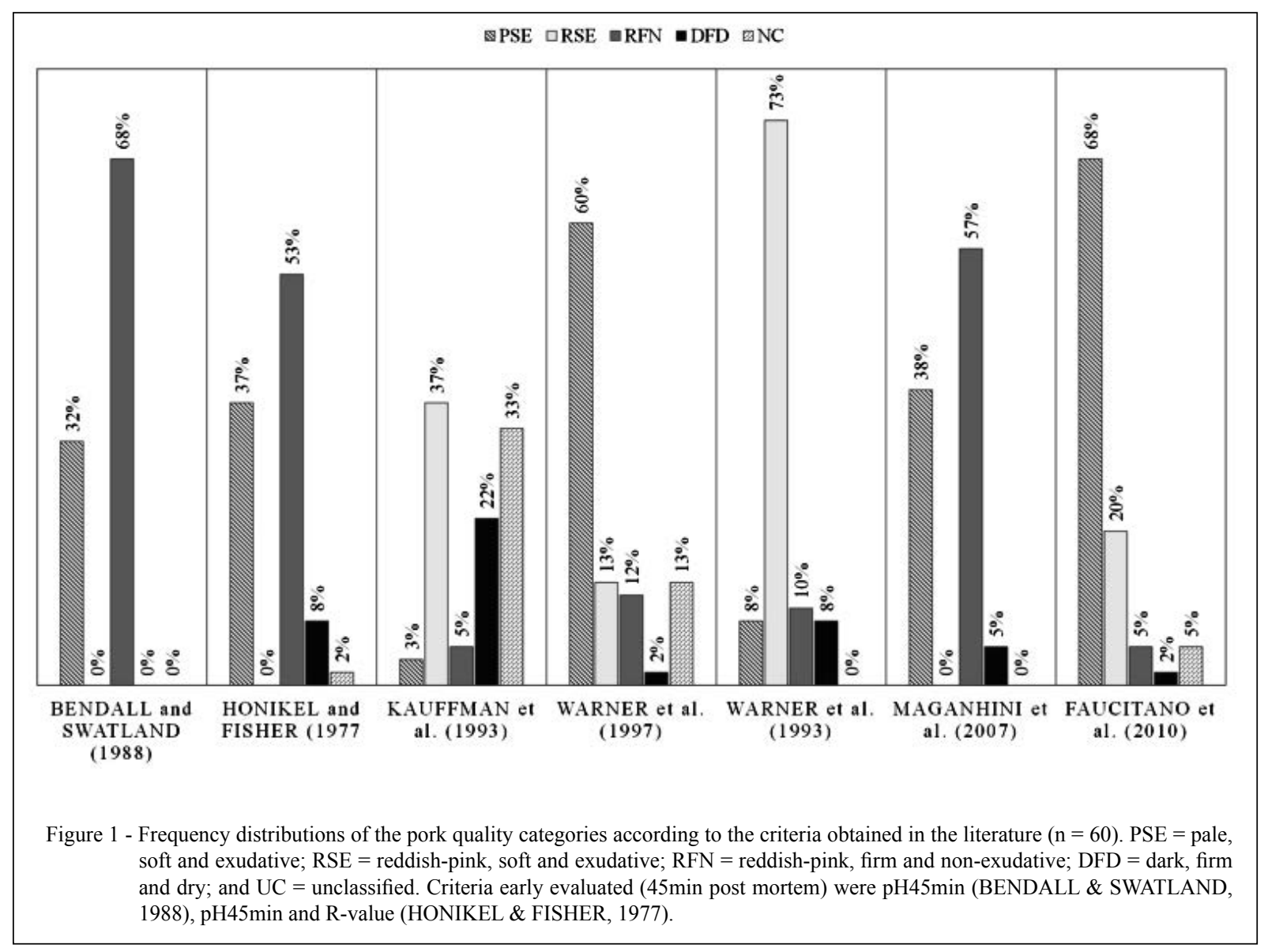

present study, the highest correlations were $(P<0.05)$ observed between $\mathrm{pH}_{45 \min }$ and WHC ( -0.52 for PDL and -0.53 for FPW) as well as between $L^{*}$ values and WHC ( 0.62 for PDL and 0.53 for FPW). Correlations of $\mathrm{pH}_{45 \min }$ and $\mathrm{WHC}$ were higher to the values $(\mathrm{r}=-0.34$ to -0.48 ) observed by DE VRIES et al. (1994), OTTO et al. (2004) and VAN OECKEL et al. (1999) when WHC was measured by PDL method, but similar to those values ( $\mathrm{r}=-0.41$ to -0.57 ) reported by DE VRIES et al. (1994) and VAN OECKEL et al. (1999) when FPW method was used. The correlations between $L^{*}$ values and WHC were also higher than values $(\mathrm{r}=0.38$ to 0.52 ) reported in the literature (DE VRIES et al., 1994; HUFF-LONERGAN et al., 2002; OTTO et al., 2004). These results confirmed that paler meat is related to higher drip loss.

KAUFFMAN et al. (1993) and WARNER et al. (1993)'s criteria are based only on $L^{*}$ and WHC (by PDL or FPW method), not considering $\mathrm{pH}_{24 \mathrm{~h}}$. The criterion proposed by KAUFFMAN et al. (1993) showed the highest frequency of
DFD (22\%) and unclassified (33\%) samples. The unclassified samples occurred because they had $L^{*}$ values lower than 52 but with PDL higher than 5\%. In contrast, the criterion proposed by WARNER et al. (1993) was able to classify all samples, wherein $73 \%$ of them were RSE. Lower values for the $L^{*}$ parameters proposed by these authors in relation to those proposed by KAUFFMAN et al. (1993) caused the differences in the frequency distributions, because $82 \%$ of the samples met concurrently the WHC parameters of a same class for both criteria. Moreover, despite being different methods, PDL and FPW were moderately correlated $(r=0.67 ; P<0.05)$.

Conversely, through the criteria based only on $\mathrm{pH}_{45 \min }$, on $\mathrm{pH}_{45 \min }$ and R-value (HONIKEL $\&$ FISHER, 1977) and only on $L^{*}$ (MAGANHINI et al., 2007), most of the samples (53 to $68 \%$ ) were classified as RFN, whereas a large part of them (32 to $38 \%$ ) was classified as PSE. Inclusion of the R-value along with $\mathrm{pH}_{45 \min }$ increased the categorization as 
PSE by $5 \%$ and as DFD by $8 \%$, thereby reducing the percentage of RFN, probably because $75 \%$ of the samples were classified in the same manner in both criteria. However, the frequency distribution according to the criterion of MAGANHINI et al. (2007) almost did not differ from these two previous criteria. Between $\mathrm{pH}_{45 \min }$ and $\mathrm{R}$-value were reported a moderate correlation $(r=-0.63 ; P<0.05)$, while none
$(P>0.05)$ correlations were observed between $L^{*}$ and $\mathrm{pH}_{45 \min }$ or R-value.

Quality attributes were also evaluated among the quality categories for each criterion (Tables 2 and 3). A same sample may be classified into different quality categories according to the criterion utilized; and therefore, the criteria showed different responses, i.e., the quality attributes

Table 2 - Quality attributes (mean \pm standard error) of the pork quality categories for the criteria proposed by BENDALL \& SWATLAND (1988), HONIKEL \& FISHER (1977), and KAUFFMAN et al. (1993)

\begin{tabular}{|c|c|c|c|c|}
\hline \multirow{2}{*}{ Quality Attributes } & \multirow{2}{*}{ Quality Categories } & \multicolumn{3}{|c|}{ - } \\
\hline & & BENDALL \& SWATLAND (1988) & HONIKEL \& FISHER (1977) & KAUFFMAN et al. (1993) \\
\hline \multirow{4}{*}{$\mathrm{pH}_{24 \mathrm{~h}}$} & PSE & $5.6 \pm 0.03^{\mathrm{a}}$ & $5.7 \pm 0.03^{\mathrm{a}}$ & $5.6 \pm 0.16^{\mathrm{a}}$ \\
\hline & RSE & - & - & $5.6 \pm 0.04^{\mathrm{a}}$ \\
\hline & RFN & $5.6 \pm 0.03^{\mathrm{a}}$ & $5.6 \pm 0.03^{\mathrm{a}}$ & $5.7 \pm 0.16^{\mathrm{a}}$ \\
\hline & DFD & - & $5.7 \pm 0.08^{\mathrm{a}}$ & $5.7 \pm 0.04^{\mathrm{a}}$ \\
\hline \multirow{4}{*}{ R-value } & PSE & $1.1 \pm 0.03^{\mathrm{a}}$ & $1.2 \pm 0.02^{\mathrm{a}}$ & $1.2 \pm 0.01^{\mathrm{a}}$ \\
\hline & RSE & - & - & $1.1 \pm 0.03^{\mathrm{ab}}$ \\
\hline & RFN & $1.0 \pm 0.02^{\mathrm{b}}$ & $1.0 \pm 0.01^{\mathrm{b}}$ & $0.9 \pm 0.01^{\mathrm{b}}$ \\
\hline & DFD & - & $1.2 \pm 0.03^{\mathrm{a}}$ & $1.0 \pm 0.03^{\mathrm{ab}}$ \\
\hline \multirow{4}{*}{$L^{*}$} & PSE & $52.3 \pm 0.6^{\mathrm{a}}$ & $52.7 \pm 0.8^{\mathrm{a}}$ & $60.8 \pm 1.0^{\mathrm{a}}$ \\
\hline & RSE & - & - & $54.2 \pm 0.3^{\mathrm{b}}$ \\
\hline & RFN & $51.5 \pm 0.6^{\mathrm{a}}$ & $51.3 \pm 0.5^{\mathrm{a}}$ & $53.4 \pm 0.7^{\mathrm{b}}$ \\
\hline & DFD & - & $50.3 \pm 2.3^{\mathrm{a}}$ & $48.5 \pm 0.8^{\mathrm{c}}$ \\
\hline \multirow{4}{*}{$a^{*}$} & PSE & $5.0 \pm 0.3^{\mathrm{a}}$ & $5.1 \pm 0.3^{\mathrm{a}}$ & $5.2 \pm 1.0^{\mathrm{a}}$ \\
\hline & RSE & - & - & $5.0 \pm 0.2^{\mathrm{a}}$ \\
\hline & RFN & $4.9 \pm 0.1^{\mathrm{a}}$ & $4.8 \pm 0.1^{\mathrm{a}}$ & $4.5 \pm 0.3^{\mathrm{a}}$ \\
\hline & DFD & - & $5.1 \pm 0.4^{\mathrm{a}}$ & $4.6 \pm 0.2^{\mathrm{a}}$ \\
\hline \multirow{4}{*}{$b^{*}$} & PSE & $5.3 \pm 0.2^{\mathrm{a}}$ & $5.5 \pm 0.3^{\mathrm{a}}$ & $7.0 \pm 0.8^{\mathrm{a}}$ \\
\hline & RSE & - & - & $5.7 \pm 0.2^{\mathrm{ab}}$ \\
\hline & RFN & $5.3 \pm 0.2^{\mathrm{a}}$ & $5.1 \pm 0.2^{\mathrm{a}}$ & $5.3 \pm 0.1^{\mathrm{ab}}$ \\
\hline & DFD & - & $5.2 \pm 0.5^{\mathrm{a}}$ & $4.7 \pm 0.3^{\mathrm{b}}$ \\
\hline \multirow{4}{*}{ PDL (\%) } & PSE & $7.8 \pm 0.3^{\mathrm{a}}$ & $7.8 \pm 0.4^{\mathrm{a}}$ & $9.9 \pm 0.5^{\mathrm{a}}$ \\
\hline & RSE & - & - & $8.1 \pm 0.4^{\mathrm{a}}$ \\
\hline & RFN & $6.0 \pm 0.4^{\mathrm{b}}$ & $5.9 \pm 0.4^{\mathrm{ab}}$ & $3.8 \pm 0.5^{\mathrm{b}}$ \\
\hline & DFD & - & $5.3 \pm 1.4^{\mathrm{b}}$ & $3.7 \pm 0.4^{\mathrm{b}}$ \\
\hline \multirow{4}{*}{ FPW (mg) } & PSE & $223 \pm 17^{\mathrm{a}}$ & $222 \pm 17^{\mathrm{a}}$ & $218 \pm 29^{\mathrm{a}}$ \\
\hline & RSE & - & - & $216 \pm 16^{\mathrm{a}}$ \\
\hline & RFN & $152 \pm 11^{\mathrm{b}}$ & $145 \pm 10^{\mathrm{b}}$ & $109 \pm 26^{\mathrm{a}}$ \\
\hline & DFD & - & $144 \pm 31^{\mathrm{b}}$ & $109 \pm 14^{\mathrm{a}}$ \\
\hline
\end{tabular}

$\mathrm{PSE}=$ pale, soft and exudative; RSE = reddish-pink, soft and exudative; RFN = reddish-pink, firm and non-exudative; DFD $=$ dark, firm and dry. $L^{*}=$ lightness; $a^{*}=$ redness; $b^{*}=$ yellowness; PDL = percentage drip loss; and FPW = filter-paper wetness.

${ }^{\mathrm{a}-\mathrm{c}}$ Values for each quality attribute, within a column, with different superscripts differ significantly at $P<0.05$ by the Tukey test.

Ciência Rural, v.46, n.12, dez, 2016. 
Table 3 - Quality attributes (mean \pm standard error) of the pork quality categories for the criteria proposed by WARNER et al. (1993; 1997), MAGANHINI et al. (2007) and FAUCITANO et al. (2010).

\begin{tabular}{|c|c|c|c|c|c|}
\hline \multirow{2}{*}{$\begin{array}{l}\text { Quality } \\
\text { Attributes }\end{array}$} & \multirow{2}{*}{$\begin{array}{l}\text { Quality } \\
\text { Categories }\end{array}$} & \multicolumn{4}{|c|}{ 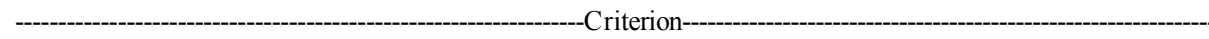 } \\
\hline & & WARNER et al. (1997) & WARNER et al. (1993) & MAGANHINI et al. (2007) & FAUCITANO et al. (2010) \\
\hline \multirow{4}{*}{$\mathrm{pH}_{24 \mathrm{~h}}$} & PSE & $5.6 \pm 0.02^{\mathrm{b}}$ & $5.5 \pm 0.07^{\mathrm{a}}$ & $5.6 \pm 0.04^{b}$ & $5.6 \pm 0.02^{\mathrm{b}}$ \\
\hline & RSE & $5.7 \pm 0.05^{\mathrm{b}}$ & $5.6 \pm 0.02^{\mathrm{a}}$ & - & $5.6 \pm 0.03^{\mathrm{b}}$ \\
\hline & RFN & $5.7 \pm 0.04^{\mathrm{b}}$ & $5.7 \pm 0.05^{\mathrm{a}}$ & $5.6 \pm 0.02^{\mathrm{b}}$ & $5.8 \pm 0.08^{\mathrm{ab}}$ \\
\hline & DFD & $6.0^{\mathrm{a}}$ & $5.7 \pm 0.1^{\mathrm{a}}$ & $5.9 \pm 0.07^{\mathrm{a}}$ & $6.0^{\mathrm{a}}$ \\
\hline \multirow{4}{*}{ R-value } & PSE & $1.1 \pm 0.02^{\mathrm{a}}$ & $1.2 \pm 0.08^{\mathrm{a}}$ & $1.1 \pm 0.03^{\mathrm{a}}$ & $1.1 \pm 0.02^{\mathrm{a}}$ \\
\hline & RSE & $1.1 \pm 0.04^{\mathrm{a}}$ & $1.1 \pm 0.02^{\mathrm{ab}}$ & - & $1.0 \pm 0.03^{\mathrm{a}}$ \\
\hline & RFN & $1.0 \pm 0.04^{\mathrm{a}}$ & $1.0 \pm 0.01^{\mathrm{b}}$ & $1.0 \pm 0.02^{\mathrm{a}}$ & $1.1 \pm 0.07^{\mathrm{a}}$ \\
\hline & DFD & $1.2^{\mathrm{a}}$ & $1.1 \pm 0.05^{\mathrm{ab}}$ & $1.0 \pm 0.07^{\mathrm{a}}$ & $1.2^{\mathrm{a}}$ \\
\hline \multirow{4}{*}{$L^{*}$} & PSE & $53.5 \pm 0.4^{\mathrm{a}}$ & $58.0 \pm 1.3^{\mathrm{a}}$ & $54.9 \pm 0.4^{\mathrm{a}}$ & $53.2 \pm 0.4^{\mathrm{a}}$ \\
\hline & RSE & $48.2 \pm 0.6^{\mathrm{b}}$ & $51.9 \pm 0.3^{\mathrm{b}}$ & - & $48.8 \pm 0.3^{\mathrm{ab}}$ \\
\hline & RFN & $47.9 \pm 0.8^{\mathrm{b}}$ & $50.9 \pm 0.8^{\mathrm{b}}$ & $50.3 \pm 0.3^{\mathrm{b}}$ & $45.0 \pm 0.9^{\mathrm{bc}}$ \\
\hline & DFD & $41.6^{\mathrm{c}}$ & $44.6 \pm 0.9^{c}$ & $43.3 \pm 1.0^{\mathrm{c}}$ & $41.6^{\mathrm{c}}$ \\
\hline \multirow{4}{*}{$a^{*}$} & PSE & $5.0 \pm 0.1^{\mathrm{a}}$ & $5.3 \pm 0.5^{\mathrm{a}}$ & $5.0 \pm 0.2^{\mathrm{a}}$ & $4.9 \pm 0.1^{\mathrm{a}}$ \\
\hline & RSE & $5.2 \pm 0.6^{\mathrm{a}}$ & $4.9 \pm 0.1^{\mathrm{a}}$ & - & $5.0 \pm 0.4^{\mathrm{a}}$ \\
\hline & RFN & $4.5 \pm 0.4^{\mathrm{a}}$ & $4.4 \pm 0.4^{\mathrm{a}}$ & $4.9 \pm 0.2^{\mathrm{a}}$ & $4.5 \pm 0.8^{\mathrm{a}}$ \\
\hline & DFD & $4.5^{\mathrm{a}}$ & $5.0 \pm 0.7^{\mathrm{a}}$ & $4.0 \pm 0.2^{\mathrm{a}}$ & $4.5^{\mathrm{a}}$ \\
\hline \multirow{4}{*}{$b^{*}$} & PSE & $5.6 \pm 0.2^{\mathrm{a}}$ & $6.6 \pm 0.5^{\mathrm{a}}$ & $5.9 \pm 0.2^{\mathrm{a}}$ & $5.5 \pm 0.1^{\mathrm{a}}$ \\
\hline & RSE & $4.8 \pm 0.4^{\mathrm{a}}$ & $5.3 \pm 0.1^{\mathrm{ab}}$ & - & $4.8 \pm 0.3^{\mathrm{a}}$ \\
\hline & RFN & $4.7 \pm 0.6^{\mathrm{a}}$ & $4.8 \pm 0.3^{\mathrm{b}}$ & $5.1 \pm 0.2^{\mathrm{a}}$ & $4.5 \pm 1.4^{\mathrm{a}}$ \\
\hline & DFD & $3.7^{\mathrm{a}}$ & $4.7 \pm 0.9^{b}$ & $3.3 \pm 0.2^{\mathrm{b}}$ & $3.7^{\mathrm{a}}$ \\
\hline \multirow{4}{*}{ PDL (\%) } & PSE & $7.8 \pm 0.3^{\mathrm{a}}$ & $8.8 \pm 1.0^{\mathrm{a}}$ & $7.8 \pm 0.5^{\mathrm{a}}$ & $7.3 \pm 0.3^{\mathrm{a}}$ \\
\hline & RSE & $6.5 \pm 0.3^{\mathrm{ab}}$ & $6.9 \pm 0.3^{\mathrm{ab}}$ & - & $5.6 \pm 0.5^{\mathrm{a}}$ \\
\hline & RFN & $3.7 \pm 0.5^{\mathrm{bc}}$ & $4.3 \pm 0.6^{\mathrm{bc}}$ & $6.0 \pm 0.3^{\mathrm{a}}$ & $3.7 \pm 1.3^{\mathrm{ab}}$ \\
\hline & DFD & $1.1^{\mathrm{c}}$ & $3.9 \pm 1.2^{\mathrm{c}}$ & $2.7 \pm 1.6^{\mathrm{b}}$ & $1.1^{\mathrm{b}}$ \\
\hline \multirow{4}{*}{ FPW (mg) } & PSE & $212 \pm 12^{\mathrm{a}}$ & $220 \pm 30^{\mathrm{a}}$ & $214 \pm 13^{\mathrm{a}}$ & $204 \pm 11^{\mathrm{a}}$ \\
\hline & RSE & $139 \pm 17^{\mathrm{ab}}$ & $196 \pm 9^{\mathrm{a}}$ & - & $139 \pm 11^{\mathrm{ab}}$ \\
\hline & RFN & $101 \pm 18^{\mathrm{ab}}$ & $78 \pm 6^{b}$ & $159 \pm 12^{\mathrm{a}}$ & $49 \pm 3^{b}$ \\
\hline & DFD & $34^{\mathrm{b}}$ & $55 \pm 10^{\mathrm{b}}$ & $45 \pm 6^{b}$ & $34^{\mathrm{b}}$ \\
\hline
\end{tabular}

PSE = pale, soft and exudative; RSE = reddish-pink, soft and exudative; RFN = reddish-pink, firm and non-exudative; DFD = dark, firm and dry. $L^{*}=$ lightness; $a^{*}=$ redness; $b^{*}=$ yellowness; PDL $=$ percentage drip loss; and FPW $=$ filter-paper wetness.

${ }^{\mathrm{a}-\mathrm{c}}$ Values for each quality attribute, within a column, with different superscripts differ significantly at $P<0.05$ by the Tukey test.

varied by pork quality categories depending on the adopted criterion.

The $\mathrm{pH}_{45 \min }$ (BENDALL \& SWATLAND, 1988) and $\mathrm{pH}_{45 \min }$ and $\mathrm{R}$-value (HONIKEL \& FISHER, 1977) criteria did not differentiate $(P>0.05)$ the $\mathrm{pH}_{24 \mathrm{~h}}$ between the quality categories. This can be explained by the absence $(P>0.05)$ of correlation between $\mathrm{pH}_{45 \min }$ and $\mathrm{pH}_{24 \mathrm{~h}}$. In addition, the $\mathrm{pH}_{24 \mathrm{~h}}$ was not used as a parameter in these criteria or even those proposed by KAUFFMAN et al. (1993) and WARNER et al. (1993), which also did not differentiate $(P>0.05)$ the $\mathrm{pH}_{24 \mathrm{~h}}$ between the quality categories. Still, the $\mathrm{pH}_{24 \mathrm{~h}}(5.9$ to 6.0$)$ of the DFD category for the criteria proposed by WARNER et al. $(1997)$ and MAGANHINI et al. (2007) was higher $(P<0.05)$ than the other categories $(5.4$ to 5.7$)$; whereas by FAUCITANO et al. (2010)'s criterion, DFD had a higher $(P<0.05) \mathrm{pH}_{24 \mathrm{~h}}$ than PSE and RSE (mean of 5.6 \pm 0.02 ), while the $\mathrm{pH}_{24 \mathrm{~h}}$ of $\mathrm{RFN}$ was similar $(P>0.05)$ to the others.

Ciência Rural, v.46, n.12, dez, 2016. 
Only WARNER et al. (1997) and FAUCITANO et al. (2010) utilized the $\mathrm{pH}_{24 \mathrm{~h}}$ as one of their parameters to classify the pork quality, which, in addition of MAGANHINI et al. (2007)'s criterion, separated the $\mathrm{pH}_{24 \mathrm{~h}}$ of the DFD category from the others. Although the rate of initial $\mathrm{pH}$ decrease can allow the detection of PSE meat, the DFD category is usually detected by the $\mathrm{pH}_{24 \mathrm{~h}}$, wherein a higher average value $(>6.0)$ is observed in DFD meats than in the others categories (RAMOS \& GOMIDE, 2007). However, none of these criteria could differentiate satisfactorily both initial and ultimate $\mathrm{pH}$ among the quality categories. KAUFFMAN et al. (1993) demonstrated that measurement of $\mathrm{pH}_{24 \mathrm{~h}}$ alone is not a reliable indicator for predicting ultimate pork quality.

As expected, RFN had a lower $(P<0.05)$ R-value than PSE and DFD (mean of 1.2 \pm 0.02 ) by the criterion proposed by HONIKEL \& FISHER (1977). According to these authors, RFN meats usually have a lower R-value than the others pork quality categories. However, for the KAUFFMAN et al. (1993) and WARNER et al. (1993)'s criteria, the R-value of RSE (1.1) and DFD (1.0 to 1.1) were similar $(P>0.05)$ to those of the other categories, while PSE (1.1 to 1.2) had a greater $(P<0.05) \mathrm{R}$-value than RFN (0.9 to 1.0$)$. In contrast, WARNER et al. (1997), MAGANHINI et al. (2007) and FAUCITANO et al. (2010)'s criteria did not differentiate $(P>0.05)$ the R-value among the quality categories.

According to the criteria proposed by KAUFFMAN et al. (1993), WARNER et al. (1997), WARNER et al. (1993) and MAGANHINI et al. (2007), DFD (41.6 to 48.5$)$ had $(P<0.05)$ lower $L^{*}$ values than the meats with a red color (RFN and RSE; 47.9 to 54.2$)$, which had $(P<0.05)$ lower $L^{*}$ values than PSE meat (53.5 to 60.8). This was expected since all these criteria used $L^{*}$ values as one the parameters to classify the pork quality. However, although the criterion proposed by FAUCITANO et al. (2010) was also able to determine differences of lightness $\left(L^{*}\right)$ among the quality categories (Table 3 ), it was not able to distinguish the red meat from pale meat (RSE from PSE) and also the red meat from dark meat (RFN from DFD). For the criteria that do not use $L^{*}$ as parameter of evaluation, the $\mathrm{pH}_{45 \min }$ alone and $\mathrm{pH}_{45 \min }$ and $\mathrm{R}$-value did not distinguish $(P>0.05)$ the $L^{*}$ values between the quality categories (mean of $51.7 \pm 0.5$ ), which may be explained by no correlation $(P>0.05)$ observed between $L^{*}$ and $\mathrm{pH}_{45 \min }$ or R-value.

For redness ( $a^{*}$ value), none of the criteria differentiated $(P>0.05)$ samples among the quality categories, while for yellowness $\left(b^{*}\right.$ value) only KAUFFMAN et al. (1993), WARNER et al. (1993) and MAGANHINI et al. (2007)'s criteria were able to differentiate them. By these criteria, DFD (3.3 to 4.7) showed $(P<0.05)$ lower yellowness than PSE (5.3 to 7.0); whereas, $\operatorname{RSE}$ (5.3 to 5.7) was similar $(P>0.05)$ to both. The response shown by the RFN category varied according to the criterion; it was similar to DFD, to PSE, or both, depending on the adopted criterion.

The differentiation of WHC, which were measured by PDL or FPW methods, among the quality categories, was the most dependent on the criterion adopted. All criteria showed some distinction among the quality categories, except for that proposed by KAUFFMAN et al. (1993), which did not differentiate FPW. Overall, as expected, DFD showed $(P<0.05)$ lower PDL (1.1 to 5.3) and FPW (34 to 144) than PSE (7.3 to 9.9 for PDL and 198 to 220 for FPW) meat. Nevertheless, the PDL and FPW of RFN and RSE meats varied with the criteria, whose values were similar to DFD, to PSE, to adjacent categories, or to both PSE and DFD, according to the criterion adopted. A likely explanation for this is that PDL and FPW were correlated $(P<0.05)$ with each other $(r=0.67)$ and with practically all parameters of the evaluated criteria, except $(P>0.05)$ with $\mathrm{pH}_{24 \mathrm{~h}}$. This would explain the wide variation in the response shown by PDL and FPW among the quality categories for the evaluated criteria (Tables 2 and 3 ).

\section{CONCLUSION}

A same sample could be classified into different quality categories according to the criterion utilized, which results in large variations in the frequency distributions and quality attributes. Therefore, the classification of pork quality depends on the adopted criterion, which indicated the need for international standardization so that the pork quality can be determined efficiently and effectively.

\section{ACKNOWLEDGEMENTS}

The authors would like to thank the Conselho Nacional de Desenvolvimento Científico e Tecnológico (CNPq) for their financial support (MCT/CNPq 476355/2012-5) and the Conselho Nacional de Desenvolvimento Científico e Tecnológico $(\mathrm{CNPq})$, Fundação de Amparo à Pesquisa do Estado de Minas Gerais (FAPEMIG) and Coordenação de Aperfeiçoamento de Pessoal de Nível Superior (CAPES) for the scholarship granted to the first (PIBIC/CNPq) and third (BPD-00398-13; post-doctoral PMPD II CAPES/FAPEMIG) authors.

\section{REFERENCES}

BARBUT, S. et al. Progress in reducing the pale, soft and exudative (PSE) problem in pork and poultry meat. Meat Science, v.79, n.1, p.46-63, 2008. Available from: <http://dx.doi.org/10.1016/j. meatsci.2007.07.031>. Accessed: Out. 02, 2015. doi: 10.1016/j. meatsci.2007.07.031. 
BENDALL, J.R.; SWATLAND, H.J. A review of the relationships of $\mathrm{pH}$ with physical aspects of pork quality. Meat Science, v.24, n.2, p.85-126, 1988. Available from: $<$ http://dx.doi.org/10.1016/0309-1740(88)900526>. Accessed: Out. 02, 2015. doi:10.1016/0309-1740(88)90052-6.

CULAU, P.O.V. et al. Effect of the Halothane Gene on the Quality of Pork. Revista Brasileira de Zootecnia, v.31, p.954-961, 2002.

DE VRIES, A.G. et al. Genetic parameters of pork quality and production traits in Yorkshire populations. Livestock Production Science, v.40, n.3, p.277-289, 1994. Available from: <http://dx.doi. org/10.1016/0301-6226(94)90095-7>. Accessed: Out. 04, 2015. doi: 10.1016/0301-6226(94)90095-7.

FAUCITANO, L. et al. Shelf life of pork from five different quality classes. Meat Science, v.84, n.3, p.466-469, 2010. Available from: $<$ http://dx.doi.org/10.1016/j.meatsci.2009.09.017>. Accessed: Out. 10, 2015. doi: 10.1016/j.meatsci.2009.09.017.

HONIKEL, K.O. et al. Sarcomere shortening of prerigor muscles and its influence on drip loss. Meat Science, v.16, n.4, p.267-282, 1986. Available from: <http://dx.doi.org/10.1016/0309-1740(86)90038$0>$. Accessed: Out. 02, 2015. doi: 10.1016/0309-1740(86)90038-0.

HONIKEL, K.O.; FISHER, C.A. A rapid method for the detection of PSE and DFD porcine muscles. Journal of Food Science, v.42, n.7, p.1633-1636, 1977.

HUFF-LONERGAN, E. et al. Correlations among selected pork quality traits. Journal of Animal Science, v.80, n.3, p.617-627, 2002.

HUFF-LONERGAN, E.; LONERGAN, S.M. Mechanisms of water-holding capacity of meat: The role of postmortem biochemical and structural changes. Meat Science, v.71, n.1, p.194-204, 2005. Available from: <http://dx.doi.org/10.1016/j. meatsci.2005.04.022>. Accessed: Out. 02, 2015. doi: 10.1016/j. meatsci.2005.04.022.

JOO, S.T. et al. Objectively predicting ultimate quality of postrigor pork musculature: I. Initial comparison of techniques. AsianAustralasian Journal of Animal Sciences, v.13, n.1, p.68-76, 2000. Available from: <http://dx.doi.org/10.5713/ajas.2000.68>. Accessed: Out. 04, 2015. doi: 10.5713/ajas.2000.68.

KAUFFMAN, R.G. et al. A comparison of methods to estimate water-holding capacity in post-rigor porcine muscle. Meat Science, v.18, n.4, p.307-322, 1986. Available from: $<$ http://dx.doi. org/10.1016/0309-1740(86)90020-3>. Accessed: Out. 04, 2015. doi: $10.1016 / 0309-1740(86) 90020-3$.

KAUFFMAN, R.G. et al. The effectiveness of examining early post-mortem musculature to predict ultimate pork quality. Meat Science, v.34, n.3, p.283-300, 1993. Available from: <http://dx.doi. org/10.1016/0309-1740(93)90078-V>. Accessed: Nov. 01, 2015. doi: 10.1016/0309-1740(93)90078-V.
MAGANHINI, M.B. et al. Meats PSE (Pale, Soft, Exudative) and DFD (Dark, Firm, Dry) of an industrial slaughterline for swine loin. Ciência e Tecnologia de Alimentos, v.27, p.69-72, 2007.

OTTO, G. et al. Comparison of different methods for determination of drip loss and their relationships to meat quality and carcass characteristics in pigs. Meat Science, v.68, n.3, p.401-409, 2004. Available from: <http://dx.doi.org/10.1016/j. meatsci.2004.04.007>. Accessed: Nov. 01, 2015. doi: 10.1016/j. meatsci.2004.04.007.

RAMOS, E.M.; GOMIDE, L.A.M. Avaliação da qualidade de carnes: fundamentos e metodologias. Viçosa: UFV, 2007. 599p.

SANTIAGO, J.C. et al. Incidência da carne PSE (pale, soft, exsudative) em suínos em razão do tempo de descanso pré-abate e sexo. Arquivo Brasileiro de Medicina Veterinária e Zootecnia, v.64, p.1739-1746, 2012.

SOMERS, C. et al. Evaluation of some objective methods for measuring pork quality. Meat Science, v.15, n.2, p.63-76, 1985. Available from: <http://dx.doi.org/10.1016/0309-1740(85)900476>. Accessed: Out. 01, 2015. doi: 10.1016/0309-1740(85)90047-6.

TAO, F.; PENG, Y. A method for nondestructive prediction of pork meat quality and safety attributes by hyperspectral imaging technique. Journal of Food Engineering, v.126, n.0, p.98-106, 2014. Available from: <http://dx.doi.org/10.1016/j. jfoodeng.2013.11.006>. Accessed: Out. 01, 2015. doi: 10.1016/j. jfoodeng.2013.11.006.

VAN OECKEL, M.J. et al. Comparison of different methods for measuring water holding capacity and juiciness of pork versus on-line screening methods. Meat Science, v.51, n.4, p.313320, 1999. Available from: <http://dx.doi.org/10.1016/S03091740(98)00123-5>. Accessed: Out. 02, 2015. doi: 10.1016/S03091740(98)00123-5.

WARNER, R.D. et al. Muscle protein changes post mortem in relation to pork quality traits. Meat Science, v.45, n.3, p.339352, 1997. Available from: <http://dx.doi.org/10.1016/S03091740(96)00116-7>. Accessed: Nov. 03, 2015. doi: 10.1016/S03091740(96)00116-7.

WARNER, R.D. et al. Quality attributes of major porcine muscles: A comparison with the Longissimus Lumborum. Meat Science, v.33, n.3, p.359-372, 1993. Available from: <http://dx.doi. org/10.1016/0309-1740(93)90007-5>. Accessed: Out. 03, 2015. doi: 10.1016/0309-1740(93)90007-5.

WARRISS, P.D.; BROWN, S.N. The relationships between initial $\mathrm{pH}$, reflectance and exudation in pig muscle. Meat Science, v.20, n.1, p.65-74, 1987. Available from: <http://dx.doi. org/10.1016/0309-1740(87)90051-9>. Accessed: nov. 04, 2015. doi: 10.1016/0309-1740(87)90051-9. 